\title{
Sensitivitas dan Kelayakan Indeks Biotik Menggunakan Makroavertebrata untuk Menentukan Status Kesehatan Sungai
}

\section{(Sensitivity and Feasibility of Biotic Index Using Macroinvertebrates to Assess River Health Status)}

\author{
Luk Luk II Maknuunn ${ }^{1 *}$, Majariana Krisanti ${ }^{2}$, Yusli Wardiatno ${ }^{2,3,4}$ \\ (Diterima Juli 2019/Disetujui Januari 2021)
}

\begin{abstract}
ABSTRAK
Pemantauan kualitas air dengan menggunakan makroavertebrata telah banyak dikembangkan oleh beberapa negara untuk memantau kualitas perairan negara mereka. Sementara itu di Indonesia, pemantauan kualitas air belum dikembangkan dengan menyesuaikan dengan kondisi alamnya. Beberapa peneliti di Indonesia menggunakan indeks biotik yang telah ada, seperti FBI, LQI, SIGNAL, dan sebagainya. Dengan demikian, penelitian ini dilakukan untuk menentukan status kualitas air dengan beberapa indeks yang telah ada dan membandingkan tingkat sensitivitas serta kelayakan indeks dalam aktivitas monitoring menggunakan matriks sederhana dan uji korelasi Pearson. Hasil interpretasi indeks biotik FBI, LQI, dan Singscore dalam menilai status kesehatan pada setiap stasiun di Sungai Brantas, Opak, Progo, dan Cileungsi berbeda-beda. Hasil uji korelasi Pearson menunjukkan bahwa sensitivitas indeks antarsungai berbeda-beda. Hal ini dipengaruhi oleh kondisi sungai dan aktivitas di sekitarnya yang memberikan masukan polutan ke dalam sungai. Indeks FBI memperoleh skor yang lebih besar dalam perhitungan skor sensitivitas indeks.
\end{abstract}

Kata kunci: makroavertebrata, monitoring, sensitivitas, sungai

\section{ABSTRACT}

Water-quality monitoring using macroinvertebrates has been developed by several countries to determine their water qualities. Meanwhile in Indonesia, water quality monitoring has not been developed to adapt to Indonesia's natural conditions. Some researchers use the existing biotic indices such as FBI, LQI, SIGNAL, and others. Therefore, this study aims to determine the status of water quality using several biotic indices and to compare the sensitivity and feasibility of indices on monitoring activities using simple matrix and Pearson correlation test. The interpretation results of FBI, LQI, and Singscore to determine water quality on each station in Brantas, Opak, Progo, and Cileungsi Rivers were different. The Pearson's correlations test showed that the sensitivities are different between rivers. Those results are affected by the river conditions and also the activities around the rivers which release the pollution into the river. The FBI index showed the greatest score number of sensitivities among the other indexes.

Keywords: macroinvertebrate, monitoring, river, sensitivity

\section{PENDAHULUAN}

Sungai merupakan ekosistem yang rentan mengalami perubahan akibat aktivitas manusia (Castello et al. 2013), seperti pertanian, perkebunan, dan pembuangan limbah, baik dari industri maupun domestik (Warman 2015). Hal ini dapat memengaruhi struktur (berupa bentuk saluran, kualitas air, atau komposisi komunitas biologis) dan fungsi sungai

\footnotetext{
1 Sekolah Pascasarjana, Fakultas Perikanan dan IImu Kelautan, Institut Pertanian Bogor, Kampus IPB Darmaga, Bogor 16680

2 Departemen Manajemen Sumberdaya Perairan, Fakultas Perikanan dan IImu Kelautan, Institut Pertanian Bogor, Kampus IPB Darmaga, Bogor 16680

3 Pusat Penelitian Lingkungan Hidup (PPLH) Institut Pertanian Bogor, Kampus IPB Darmaga, Bogor 16680

4 Pusat Kajian Sumberdaya Pesisir dan Lautan, Institut Pertanian Bogor, Kampus IPB Darmaga, Bogor 16680

* Penulis Korespondensi: Email: luklukilma94@gmail.com
}

(berupa proses metabolisme, dekomposisi, atau produktivitas sekunder) (Angeler et al. 2014). Perubahan yang terus menerus terjadi dapat menimbulkan kerusakan serta bahaya bagi makhluk hidup yang bergantung pada sumber daya air tersebut (Effendi 2003). Dengan demikian, diperlukan aktivitas pemantauan kualitas perairan dalam rangka pengelolaan sumber daya perairan.

Upaya pemantauan kualitas perairan dapat dilakukan dengan menggunakan analisis fisika dan kimia air serta biologi. Akan tetapi, penggunaan analisis fisika dan kimia membutuhkan waktu yang lama dalam pengambilan data untuk mendapatkan hasil yang akurat (Blakely et al. 2014). Selain itu, dalam beberapa kondisi sering kali perubahan ekologi sungai tidak terlihat secara jelas. Dengan demikian, diperlukan pemerikasaan yang lebih rinci menggunakan biota akuatik (Friedrich et al. 1996). Penggunaan makroavertebrata untuk menentukan status ekologi sungai telah banyak digunakan di 
berbagai negara ( $\mathrm{Li}$ et al. 2010). Pemilihan biota makroavertebrata sebagai bioindikator dilakukan karena biota ini memiliki keunggulan, seperti sebagian besar hidupnya menetap di dasar perairan dan memiliki rentang hidup yang relatif panjang (Uherek\&Gouveia 2014). Makroavertebrata juga memiliki banyak spesies pada berbagai macam tingkat trofik serta toleransi terhadap polusi (Cook 1976).

Pemantauan kualitas air dengan pendekatan biologi banyak telah dikembangkan, $60 \%$ di antaranya dilakukan berdasarkan analisis makroavertebrata (Kalyoncu \& Zeybek 2011). Sebagian besar pendekatan biologi ini bersifat khusus untuk daerah geografis tertentu, seperti SingScore (Singapore score) di Singapura (Blakely et al. 2014), Family Biotic Index (FBI) di wilayah Wisconsin (Hilsenhoff 1982), dan sebagainya. Di Indonesia, pendekatan biologi dalam pemantuan kualitas air belum dikembangkan. Sebagian besar peneliti di Indonesia dalam menentukan kualitas air menggunakan indeks biotik, seperti FBI, LQI, dan SIGNAL (Krisanti et al. 2017; Khairuddin et al. 2016). Berdasarkan beberapa hal yang telah dikemukakan maka dilakukan penelitian ini yang bertujuan untuk menentukan status kesehatan sungai serta membandingkan tingkat sensitivitas indeks biotik FBI, LQI, dan SingScore sebagai indeks penentu status ekologi sungai yang ada di Indonesia.

\section{METODE PENELITIAN}

\section{Studi Area}

Pengambilan data dilakukan pada bulan April, Mei, dan Oktober 2018 di Sungai Brantas (Jawa Timur),
Sungai Opak dan Sungai Progo (Daerah Istimewa Yogyakarta), serta Sungai Cileungsi (Jawa Barat) yang memiliki perbedaan letak ketinggian hulu. Pengambilan contoh makroavertebrata dan parameter kualitas air dilakukan satu kali pada masing-masing sungai dengan 10 stasiun untuk Sungai Brantas dan Cileungsi, 6 stasiun untuk Sungai Opak, dan 4 stasiun untuk Sungai Progo. Penentuan stasiun dilakukan berdasarkan perbedaan orde, letak ketinggian, penutupan kanopi ruas sungai, dan tata guna lahan yang memengaruhi besar beban polutan yang masuk pada perairan. Kondisi ini selanjutnya akan memengaruhi jenis polutan yang mendominasi dan hanya dapat dideteksi oleh indeks biotik tertentu sesuai dengan tingkat sensitivitasnya terhadap jenis polutan. Lokasi stasiun pengamatan dapat dilihat pada Gambar 1.

\section{Pengambilan Contoh}

Pengukuran parameter fisika (suhu, kecepatan arus, dan tipe substrat) dan sampel parameter kimia (DO dan $\mathrm{pH}$ ) dilakukan secara in situ. Sementara itu, parameter kimia, seperti COD diukur secara ex situ. Analisis laboratorium untuk parameter kimia COD menggunakan metode berdasarkan American Public Health Association (APHA 2012) yang dilakukan di Laboratorium Produktivitas Lingkungan Perairan, Departemen Manajemen Sumberdaya Perairan, Institut Pertanian Bogor.

Pengambilan contoh makroavertebrata dilakukan dengan menggunakan surber berukuran bingkai $30 \mathrm{~cm}$ $\times 30 \mathrm{~cm}$ dengan mesh size $1 \mathrm{~mm}$. Surber diletakkan menghadap ke arah arus yang datang, dengan bagian surber yang berupa bingkai diletakkan di dasar

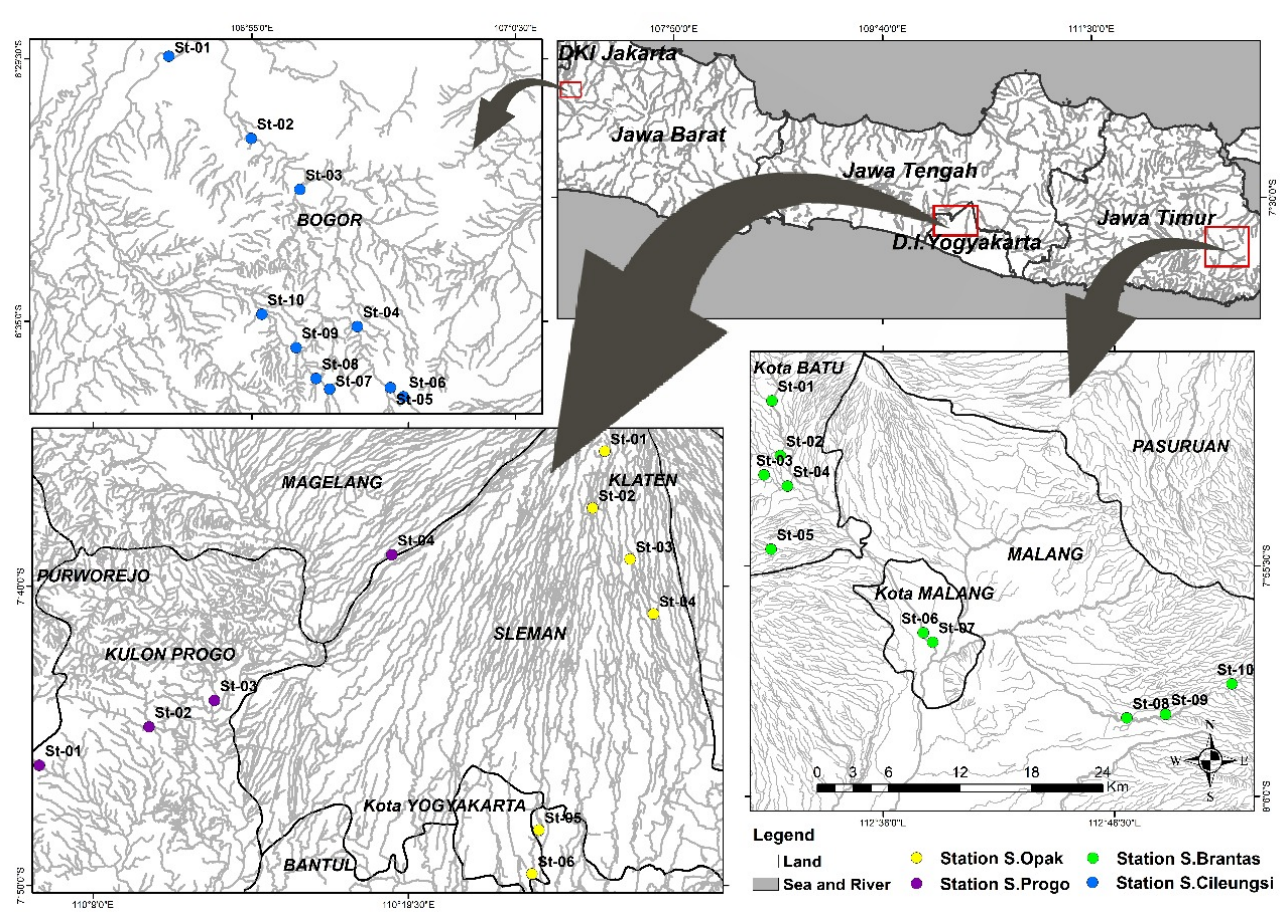

Gambar 1 Lokasi pengambilan sampel makroavertebrata di Sungai Brantas (kanan bawah), Sungai Opak, dan Sungai Progo (kiri bawah), dan Sungai Cileungsi (kiri atas). 
perairan. Substrat dalam bingkai diganggu selama lima menit sehingga biota akan hanyut dan masuk ke arah jaring. Kemudian surber diangkat, contoh makroavertebrata dimasukkan ke dalam wadah dan diberi alkohol $70 \%$ dan rose bengal. Selanjutnya contoh dibawa ke laboratorium untuk disortir dan diidentifikasi sampai dengan tingkat genus mengikuti petunjuk buku identifikasi McCafferty (1983) dan Pennak (1978). Penyortiran dan pengidentifikasian contoh makroavertebrata dilakukan di Laboratorium Biomikro 1, Departemen Manajemen Sumberdaya Perairan, Institut Pertanian Bogor.

\section{Analisis Data}

Analisis data yang digunakan untuk mengetahui struktur komunitas makroavertebrata antara lain adalah kepadatan (Brower et al. 1990), indeks keanekaragaman Shannon-Wiener (Krebs 1989), indeks keseragaman (Krebs 1989), dan indeks dominasi (Odum 1993). Adapun indeks biota yang digunakan dalam penelitian ini adalah Family Biotic Index atau FBI (Hilsenhoff 1988; Moran 2016), Lincoln Quality Index atau LQI (Mason 1991) serta SingScore atau Singapore Biotic Index (Blakely et al. 2014). Analisis ragam (ANOVA) satu arah dan uji BNT digunakan untuk mengetahui perbedaan sungai berdasarkan jumlah family dan kepadatan pada masing-masing sungai. Komparasi tingkat sensitivitas indeks biota yang digunakan dilakukan dengan dua metode. Pertama, metode matriks sederhana, yakni memberikan skor pada parameter yang memengaruhi sensitivitas indeks (Wildan 2017), seperti jumlah kelompok biota yang diperoleh mampu dideteksi indeks, jumlah kelompok biota sensitif yang dimiliki indeks, dan penggunaan kelimpahan dalam perhitungan. Kedua, metode korelasi Pearson untuk mengetahui hubungan antara parameter fisika kimia dengan indeks biologi.

\section{HASIL DAN PEMBAHASAN}

\section{Karakteristik Fisika Kimia Perairan}

Hasil analisis ragam parameter kualitas air antarsungai ditampilkan pada Tabel 1. Ditemukan perbedaan signifikan pada parameter fisika-kimia yang diukur $(p<0,05)$ kecuali pada parameter COD. Salah satu faktor penyebabnya adalah adanya kemiripan aktvitas manusia yang ada di sekitar masing-masing sungai, seperti aktivitas pertanian, perhutanan, perkebunan, penambangan pasir, dan lainnya yang menyumbang masukan bahan organik di perairan. Parameter COD menggambarkan jumlah pencemaran bahan organik ( $\mathrm{Li}$ et al. 2018) yang dipengaruhi oleh berbagai faktor, seperti topografi, musim, dan aktivitas manusia (Abdullah et al. 2003; Hudson et al. 2007).

Hasil uji lanjut BNT menunjukkan bahwa Sugai Brantas memiliki parameter fisika-kimia yang berbeda signifikan dari sungai lainnya $(p<0,05)$ pada semua parameter, kecuali COD. Perbedaan ini disebabkan, salah satunya, karena Sungai Brantas memiliki letak hulu yang paling tinggi, yakni lebih dari 1000 mdpl dibandingkan dengan sungai lainnya, yang selanjutnya memengaruhi nilai parameter lain, seperti suhu $(p=$ $0,00)$, oksigen terlarut atau $\mathrm{DO}(p=0,02)$, kecepatan arus $(p=0,019)$, dan tutupan kanopi $(p=0,00)$. Hal ini diperkuat dengan hasil uji korelasi yang menunjukkan bahwa parameter ketinggian lokasi berkorelasi positif dengan parameter suhu dan DO $(p<0,05)$.

\section{Struktur Komunitas Makroavertebrata}

Secara keseluruhan, jumlah makroavertebrata yang ditemukan pada keempat sungai berkisar antara 38-65 genus, 21-31 famili, dan 7-11 ordo. Rata-rata jumlah ordo, famili, dan genus terbanyak ditemukan pada Sungai Progo yang diikuti oleh Sungai Cileungsi. Ditemukan sebanyak tiga ordo yang mendominasi pada setiap sungai dengan komposisi yang berbeda-

Tabel 1 Rata-rata \pm standar deviasi (nilai minimum-maksimum pada saat pengukuran) parameter lingkungan di Sungai Brantas, Opak, Progo, dan Cileungsi

\begin{tabular}{|c|c|c|c|c|}
\hline Parameter & Sungai Brantas* & Sungai Opak & Sungai Progo & Sungai Cileungsi \\
\hline \multirow[t]{2}{*}{ Ketinggian lokasi* } & $909,9 \pm 297,33$ & $377,33 \pm 284,28$ & $266 \pm 132,99$ & $450,5 \pm 250,61$ \\
\hline & $(430-1268)$ & $(95-873)$ & $(126-444)$ & $(125-840)$ \\
\hline \multirow[t]{2}{*}{ Suhu* } & $22,74 \pm 2,81$ & $28,55 \pm 2,12$ & $26,3 \pm 4,23$ & $31,49 \pm 5,72$ \\
\hline & $(18,2-26,9)$ & $(25,2-31,6)$ & $(20,7-30,9)$ & $(25,7-41,2)$ \\
\hline \multirow[t]{2}{*}{$\mathrm{pH}^{*}$} & $7,39 \pm 0,59$ & $6,49 \pm 0,29$ & $6,41 \pm 0,66$ & $7,83 \pm 1,07$ \\
\hline & $(6,36-8,04)$ & $(6,1-6,8)$ & $(5,45-6,96)$ & $(5,2-9,11)$ \\
\hline \multirow[t]{2}{*}{$\mathrm{DO}\left(\mathrm{mg} . \mathrm{I}^{-1}\right)^{\star}$} & $7,52 \pm 0,81$ & $6,15 \pm 0,63$ & $5,98 \pm 0,44$ & $8,25 \pm 1,52$ \\
\hline & $(5,8-8,4)$ & $(5,1-6,8)$ & $(5,5-6,4)$ & $(5,9-10,1)$ \\
\hline \multirow[t]{2}{*}{$\operatorname{COD}\left(\mathrm{mg}^{-\mathrm{I}^{-1}}\right)$} & $67,93 \pm 4,13$ & $66,04 \pm 4,45$ & $67,76 \pm 2,74$ & $60,97 \pm 27,92$ \\
\hline & $(62,61-75,92)$ & $(61,75-74,2)$ & $(65,18-70,34)$ & $(11,52-88,8)$ \\
\hline \multirow[t]{2}{*}{ Arus $\left(m \cdot \text { detik }^{-1}\right)^{\star}$} & $0,96 \pm 0,29$ & $0,42 \pm 0,19$ & $0,45 \pm 0,26$ & $0,22 \pm 0,09$ \\
\hline & $(0,5-1,4)$ & $(0,04-0,55)$ & $(0,15-0,75)$ & $(0,13-0,4)$ \\
\hline \multirow[t]{2}{*}{ Tutupan kanopi (\%)* } & $36 \pm 41,69$ & $25 \pm 28,98$ & $21,25 \pm 42,5$ & $15 \pm 18,41$ \\
\hline & $(0-100)$ & $(0-75)$ & $(0-85)$ & $(0-50)$ \\
\hline
\end{tabular}

Keterangan: *Parameter berbeda signifikan $(p<0,05)$. 
beda, seperti Sungai Brantas didominasi oleh Diptera $(49,68 \%)$, Ephemeroptera (26,95\%), dan Trichoptera $(19,21 \%)$; Sungai Opak didominasi oleh Ephemeroptera $(48,89 \%)$, Trichoptera $(27,15 \%)$, dan Diptera (14,94\%); Sungai Progo didominasi oleh Ephemeroptera (37,96\%), Trichoptera (26,53\%), dan Diptera (24,53\%); dan Sungai Cileungsi didominasi oleh Diptera $(47,24 \%)$, Ephemeroptera $(33,1 \%)$, dan Trichoptera (10,66\%). Hasil perhitungan indeks keanekaragaman, keseragaman, dan dominasi ditampilkan pada Tabel 2. Rata-rata indeks keanekaragaman tertinggi ditemukan pada Sungai Progo yang diikuti oleh Sungai Cileungsi. Hasil ini dipengaruhi oleh keberadaan tutupan kanopi ataupun vegetasi riparian yang menjadi sumber makanan bagi makroavertebrata. Menurut Patang et al. (2018) penurunan vegetasi riparian mengakibatkan diversitas makroavertebrata yang rendah. Nilai indeks dominasi tertinggi ditemukan pada Sungai Opak dengan nilai 0,54 . Kondisi ini dipengaruhi oleh gangguan aktivitas manusia yang besar dan banyak di stasiun tersebut, seperti permukiman dan pembuangan sampah yang mengakibatkan hanya kelompok makroavertebrata tertentu yang toleran terhadap polutan yang mampu bertahan hidup. Secara umum, keberadaan makroavertebrata dari segi komposisi dan kepadatan di sungai dipengaruhi oleh berbagai faktor, seperti suhu (Ward 1992), kecepatan arus (Everaert 2014), ketersediaan makanan dalam bentuk bahan organik yang keberadaannya dipengaruhi oleh vegetasi riparian atau tutupan kanopi (Oruta et al. 2017), tipe substrat sebagai habitat mereka (Nakin et al. 2017; Yunitawati et al. 2012), dan lain-lain.

\section{Komparasi Indeks Biotik FBI, LQI, dan Singscore}

Hasil perhitungan indeks biotik menunjukkan bahwa status ekologi setiap sungai bervariasi mulai dari sangat rendah hingga excellent sebagaimana disajikan pada Tabel 3 hingga Tabel 5. Penggunaan tiga indeks biotik menunjukkan interpretasi yang berbeda pada setiap stasiun pada masing-masing sungai. Perbedaan interpretasi ini secara tidak langsung menggambarkan keakuratan masing-masing indeks dalam menentukan status kesehatan sungai. Perbedaan keakuratan antarindeks biotik disebabkan oleh perbedaan nilai toleransi taksa yang diberikan oleh masing-masing indeks (Wimbaningrum et al. 2016).

Hasil uji korelasi antara parameter fisika kimia dengan indeks biotik yang digunakan menunjukkan hasil yang berbeda antarsungai sebagaimana dapat dilihat pada Tabel 6. Berdasarkan tabel tersebut, indeks biotik FBI dan LQI memiliki sensitivitas yang lebih tinggi pada Sungai Brantas karena berhubungan erat dengan tutupan kanopi. Selanjutnya, indeks biotik FBI dan Singscore memiliki sensitivitas yang lebih tinggi pada Sungai Opak karena masing-masing berhubungan erat secara berturut-turut dengan tutupan kanopi serta COD. Adapun di Sungai Progo, indeks biotik $\mathrm{FBI}$ lebih sensitif karena berhubungan erat dengan suhu, $\mathrm{pH}$, dan tutupan kanopi. Sementara itu, di Sungai Cileungsi tidak ditemukan adanya hubungan indeks biotik dengan parameter fisika kimia. Dengan demikian, dapat dikatakan bahwa perbedaan tingkat sensitivitas indeks biotik antarsungai disebabkan oleh perbedaan kondisi lingkungan dan aktivitas di sekitar sungai. Kedua faktor tersebut memengaruhi jenis polutan yang masuk ke sungai.

Hasil komparasi sensitivitas dan kelayakan ketiga indeks biotik menggunakan metode maktriks (Tabel 7) menunjukkan bahwa FBI dan LQI memiliki skor yang lebih tinggi pada parameter biota sensitif dan biota yang mampu dideteksi oleh indeks biotik. Hal ini menunjukkan bahwa kedua indeks biotik tersebut lebih sensitif dibandingkan dengan Singscore. Sementara itu, total perolehan skor sensitivitas indeks tertinggi didapatkan pada indeks biotik FBI. Salah satu faktor

Tabel 2 Indeks Keanekaragaman (H'), keseragaman (E), dan dominasi (C) di Sungai Brantas, Opak, Progo, dan Cileungsi

\begin{tabular}{|c|c|c|c|c|c|c|c|c|c|}
\hline DAS & Stasiun & $\mathrm{H}$ & $E$ & C & DAS & Stasiun & $\mathrm{H}$ & $E$ & $\mathrm{C}$ \\
\hline \multirow{10}{*}{$\begin{array}{l}\text { Sungai } \\
\text { Brantas }\end{array}$} & 1 & 2,49 & 0,65 & 0,30 & \multirow{4}{*}{ Sungai Progo } & 1 & 3,66 & 0,86 & 0,10 \\
\hline & 2 & 2,61 & 0,70 & 0,23 & & 2 & 4,32 & 0,84 & 0,08 \\
\hline & 3 & 2,36 & 0,56 & 0,31 & & 3 & 3,09 & 0,74 & 0,17 \\
\hline & 4 & 2,23 & 0,70 & 0,26 & & 4 & 2,92 & 0,77 & 0,18 \\
\hline & 5 & 2,52 & 0,66 & 0,31 & \multirow{12}{*}{$\begin{array}{l}\text { Sungai } \\
\text { Cileungsi }\end{array}$} & 1 & 2,07 & 0,69 & 0,34 \\
\hline & 6 & 2,13 & 0,67 & 0,27 & & 2 & 3,48 & 0,85 & 0,11 \\
\hline & 7 & 1,64 & 0,71 & 0,36 & & 3 & 3,58 & 0,76 & 0,12 \\
\hline & 8 & 2,23 & 0,67 & 0,27 & & 4 & 2,58 & 0,78 & 0,27 \\
\hline & 9 & 2,24 & 0,75 & 0,30 & & 5 & 3,76 & 0,83 & 0,10 \\
\hline & 10 & 2,01 & 0,60 & 0,32 & & 6 & 2,25 & 0,56 & 0,35 \\
\hline \multirow{6}{*}{$\begin{array}{l}\text { Sungai } \\
\text { Opak }\end{array}$} & 1 & 2,15 & 0,57 & 0,39 & & 7 & 3,07 & 0,75 & 0,15 \\
\hline & 2 & 1,87 & 0,80 & 0,36 & & 8 & 3,62 & 0,79 & 0,12 \\
\hline & 3 & 2,53 & 0,65 & 0,34 & & 9 & 3,17 & 0,70 & 0,19 \\
\hline & 4 & 3,26 & 0,77 & 0,18 & & 10 & 3,71 & 0,82 & 0,10 \\
\hline & 5 & 1,43 & 0,45 & 0,54 & & & & & \\
\hline & 6 & 2,67 & 0,70 & 0,21 & & & & & \\
\hline
\end{tabular}


Tabel 3 Nilai LQI di Sungai Brantas, Opak, Progo, dan Cileungsi

\begin{tabular}{|c|c|c|c|c|c|c|c|}
\hline DAS & OQR & LQI & Interpretasi & DAS & OQR & LQI & Interpretasi \\
\hline & 2,5 & $\mathrm{~F}$ & Rendah & & 4,5 & $B$ & Baik \\
\hline & 2,5 & $F$ & Rendah & & 3,0 & $E$ & Sedang \\
\hline & 3,5 & D & Sedang & Sungal Progo & 3,0 & $E$ & Sedang \\
\hline & 1,0 & I & Sangat rendah & & 3,5 & $\mathrm{D}$ & Sedang \\
\hline Sungai & 5,5 & $A+$ & Excellent & & 1,0 & I & Sangat rendah \\
\hline \multirow[t]{8}{*}{ Brantas } & 1,0 & I & Sangat rendah & & 3,0 & $E$ & Sedang \\
\hline & 1,5 & $\mathrm{H}$ & Sangat rendah & & 3,5 & D & Sedang \\
\hline & 1,0 & 1 & Sangat rendah & & 2,0 & $\mathrm{G}$ & Rendah \\
\hline & 1,0 & I & Sangat rendah & Sungai & 3,5 & $\mathrm{D}$ & Sedang \\
\hline & 2,0 & G & Sangat rendah & Cileungsi & 3,0 & $E$ & Sedang \\
\hline & 3,0 & $\mathrm{E}$ & Sedang & & 3,5 & $\bar{D}$ & Sedang \\
\hline & 1,5 & $\mathrm{H}$ & Sangat rendah & & 3,5 & $D$ & Sedang \\
\hline & 2,5 & $\mathrm{~F}$ & Rendah & & 3,0 & $E$ & Sedang \\
\hline \multirow{3}{*}{ Sungai Opak } & 3,5 & D & Sedang & & 6,0 & $A++$ & Excellent \\
\hline & 1,5 & $\mathrm{H}$ & Sangat rendah & & & & \\
\hline & 2,5 & $\mathrm{~F}$ & Rendah & & & & \\
\hline
\end{tabular}

Tabel 4 Nilai FBI di Sungai Brantas, Opak, Progo, dan Cileungsi

\begin{tabular}{llllll}
\hline DAS & FBI & Interpretasi & DAS & FBI & Interpretasi \\
\hline & 5,48 & Sedang & & 5,41 & Sedang \\
& 5,61 & Sedang & Sungai Progo & 2,47 & Excellent \\
& 5,85 & Agak buruk & & 1,75 & Excellent \\
& 5,29 & Sedang & & 2,37 & Excellent \\
\cline { 2 - 5 } Sungai Brantas & 3,87 & Sangat baik & & 7,81 & Sangat buruk \\
& 6,72 & Buruk & & 4,44 & Baik \\
& 6,44 & Agak buruk & & 4,88 & Baik \\
& 6,44 & Agak buruk & & 5,86 & Agak buruk \\
& 5,31 & Sedang & & 6,38 & Agak buruk \\
& 4,89 & Baik & & 7,75 & Sangat buruk \\
& 4,12 & Sangat baik & & 6,34 & Agak buruk \\
& 3,91 & Sangat baik & & 5,41 & Sedang \\
& 5,82 & Agak buruk & & 4,77 & Sedang \\
& 2,45 & Excellent & & & Sangat baik \\
\hline
\end{tabular}

Tabel 5 Nilai Singscore di Sungai Brantas, Opak, Progo, dan Cileungsi

\begin{tabular}{|c|c|c|c|c|c|}
\hline DAS & SingScore & Interpretasi & DAS & SingScore & Interpretasi \\
\hline \multirow{10}{*}{$\begin{array}{l}\text { Sungai } \\
\text { Brantas }\end{array}$} & 120 & Baik sekali & \multirow{4}{*}{ Sungai Progo } & 122 & Baik sekali \\
\hline & 108 & Baik & & 113 & Baik \\
\hline & 118 & Baik & & 123 & Baik sekali \\
\hline & 129 & Baik sekali & & 127 & Baik sekali \\
\hline & 115 & Baik & \multirow{12}{*}{$\begin{array}{l}\text { Sungai } \\
\text { Cileungsi }\end{array}$} & 53 & Rendah \\
\hline & 108 & Baik & & 126 & Baik sekali \\
\hline & 93 & Sedang & & 136 & Baik sekali \\
\hline & 200 & Baik sekali & & 95 & Sedang \\
\hline & 100 & Baik & & 126 & Baik sekali \\
\hline & 90 & Sedang & & 97 & Sedang \\
\hline \multirow{6}{*}{ Sungai Opak } & 109 & Baik & & 130 & Baik sekali \\
\hline & 107 & Baik & & 125 & Baik sekali \\
\hline & 115 & Baik & & 134 & Baik sekali \\
\hline & 135 & Baik sekali & & 148 & Baik sekali \\
\hline & 107 & Baik & & & \\
\hline & 80 & Sedang & & & \\
\hline
\end{tabular}


Tabel 6 Hasil korelasi Pearson antara parameter fisika-kimia dengan indeks biotik

\begin{tabular}{llllllll}
\hline DAS & Parameter & Suhu & $\mathrm{pH}$ & DO & COD & Arus & $\begin{array}{l}\text { Tutupan } \\
\text { kanopi }\end{array}$ \\
\hline \multirow{2}{*}{ Sungai } & FBI & 0,482 & 0,450 & 0,284 & 0,333 & 0,290 & $-0,705^{*}$ \\
Brantas & LQI & $-0,241$ & $-0,53$ & 0,228 & $-0,326$ & $-0,61$ & $0,818^{* *}$ \\
& SingScore & 0,056 & 0,355 & $-0,382$ & $-0,198$ & $-0,087$ & $-0,242$ \\
\hline \multirow{3}{*}{ Sungai Opak } & FBI & $-0,32$ & 0,243 & 0,394 & $-0,191$ & $-0,39$ & $-0,57$ \\
& LQI & $-0,791$ & 0,197 & 0,639 & 0,385 & $-0,527$ & $0,926^{* *}$ \\
& SingScore & $-0,171$ & 0,571 & 0,406 & $0,836^{*}$ & $-0,207$ & 0,717 \\
\hline \multirow{2}{*}{ Sungai Progo } & FBI & $-0,956^{*}$ & $-0,996^{* *}$ & 0,577 & $-0,623$ & 0,857 & $0,981^{*}$ \\
& SingScore & $-0,874$ & $-0,922$ & 0,746 & $-0,37$ & 0,913 & 0,943 \\
\multirow{2}{*}{ Sungai } & FBI & 0,147 & 0,071 & 0,526 & 0,752 & 0,24 & 0,085 \\
Cileungsi & LQI & $-0,482$ & $-0,15$ & 0,075 & 0,025 & 0,049 & 0,495 \\
& SingScore & $-0,375$ & 0,218 & 0,399 & 0,132 & $-0,373$ & 0,213 \\
\hline
\end{tabular}

Keterangan: ${ }^{* *}$ dan * berkorelasi secara signifikan pada derajat 0,01 dan 0,05 (2 arah).

Tabel 7 Perhitungan matriks sensitivitas indeks

\begin{tabular}{lcccc}
\hline \multirow{2}{*}{ Parameter } & \multicolumn{3}{c}{ Indeks } & Kriteria skor \\
\cline { 2 - 4 } & FBI & LQI & Singscore & $1(<50 \%), 2(51-74 \%), 3(>75 \%)$ \\
Biota sensitif & 3 & 2 & 1 & $1(<50 \%), 2(51-74 \%), 3(>75 \%)$ \\
Biota yang terdeteksi & 2 & 2 & 1 & 0 (relatif), 1 (individu) \\
Kelimpahan & 1 & 0 & 0 & \\
\hline Total skor & 6 & 4 & 2 & \\
\hline
\end{tabular}

penyebabnya adalah FBI mampu mendeteksi lebih banyak makroavertebrata yang ditemukan pada keempat sungai dibandingkan indeks yang lain. Krisanti et al. (2010) menyatakan bahwa FBI lebih banyak memberikan skor terhadap famili makroavertebrata yang umum ditemukan di Indonesia dibandingkan dengan indeks biotik yang lain. Hasil interpretasi menggunakan LQI lebih fluktuatif dibandingkan dengan FBI karena beberapa famili makroavertebrata belum memiliki nilai toleransi (Hendrasarie \& Januar 2019). Serupa dengan LQI, famili makroavertebrata yang ditemukan di Indonesia hanya sedikit yang memiliki nilai toleransi pada Singscore. Dalam perhitungannya, berbeda dari LQI dan Singscore yang menggunakan kelimpahan relatif, indeks $\mathrm{FBI}$ lebih unggul karena menggunakan kelimpahan individu yang dinilai mampu mendeteksi perubahan struktur makroavertebrata meski dalam intensitas kecil. Selain itu, indeks biotik FBI memiliki kepekaan dalam mendeteksi peningkatan nutrisi dan sedimen, pencemaran organik, serta keterbatasan kandungan oksigen terlarut (Moran 2016). Akan tetapi, indeks biotik $\mathrm{FBI}$ memiliki kelemahan yang sama dengan LQI dan Singscore dari sisi penggunaan level identifikasi family. Level identifikasi ini kurang sensitif dibandingkan dengan level identifikasi genus atau spesies (WAV 2003). Dengan demikian, indeks biotik FBI dinilai lebih sensitif dan layak digunakan untuk memantau status kesehatan sungai di Indonesia, di samping menggunakan indeks biotik lainnya.

\section{KESIMPULAN}

Hasil interpretasi status kesehatan Sungai Brantas, Opak, Progo, dan Cileungsi berbeda-beda antarindeks bergantung pada tingkat sensitivitas indeks. Dalam pemantauan kualitas air sungai di Indonesia, penggunaan indeks biotik $\mathrm{FBI}$ sangat disarankan karena memiliki sensitivitas yang lebih tinggi di samping penggunaan indeks biotik lainnya.

\section{UCAPAN TERIMA KASIH}

Penulis menyampaikan terima kasih kepada Prof. Dr. Ir. Arif Sabdo Yuwono, MSc dan SEAMEO BIOTROP yang telah memberikan dana penelitian sehingga penelitian ini terlaksana.

\section{DAFTAR PUSTAKA}

Abdullah MP, Yew CH, Ramli MS, Ali R. 2003. Trihalomethanes (THMs) in Malaysian drinking water. Malaysian Journal of Chemistry. 5(1): 56-66

Angeler DG, Allen CR, Birgé HE, Drakare S, McKie BG, Johnson RK. 2014. Assessing and managing freshwater ecosystems vulnerable to environmental change. AMBIO. 43: 113-125. https:// doi.org/10.1007/s13280-014-0566-z 
[APHA] American Public Health Association. 2012. Standard methods for the examination of water and wastewater. Washington D.C. (US): American Public Association Inc.

Blakely TJ, Eikaas HS, Harding JS. 2014. The Singscore: a macroinvertebrate biotic index for assessing the health of Singapore's stream and canals. Raffles Bulletin of Zoology. 62: 540-548

Brower JE, Zar JH, von Ende CN. 1990. Field and laboratory methods for general ecology. Ed ke-3. lowa (US): Wm C Brown Co Publisher. $194 \mathrm{p}$

Castello L, McGrath DG, Hess LL, Coe MT, Lefebvre PA, Petry P, Macedo MN, Reno VF, Arantes CC. 2013. The vulnerability of Amazon freshwater ecosystems. Conservation Letters. 6(4): 217-229. https://doi.org/10.1111/conl.12008

Cook SEK. 1976. Quest for an index of community structure sensitive to water pollution. Environmental Pollution. 11(4): 269-288. https://doi.org/ 10.1016/0013-9327(76)90067-7

Effendi H. 2003. Telaah Kualitas Air bagi Pengelolaan Sumberdaya dan Lingkungan Perairan. Yogyakarta (ID): Kanisisus

Everaert G, Neve JD, Boets $P$, Domanguez-Granda $L$, Mereta ST, Ambelu A, Hoang TH, Goethals PLM, Thas O. 2014. Comparison of the abiotic preferences of macroinvertebrates in tropical river basins. Plos One. 9(10): e108898. https:// doi.org/10.1371/journal.pone.0108898

Friedrich G, Chapman D, Beim A. 1996. Water Quality Assessments-A Guide to Use of Biota, Sediments and Water in Environmental Monitoring; Chapman D, editor. Cambridge (UK): F \& FN Spon

Hendrasarie N dan Januar. 2019. Pemetaan Kualitas Air di Kali Surabaya Berdasarkan Indeks Makroinvertebrata Benthos dengan Model Wintwins 2.3. Jurnal Envirotek. 11(2): 45-52. https:// doi.org/10.33005/envirotek.v11i2.5

Hilsenhoff WL. 1982. Using a biotic index to evaluate water quality in streams. Technical bulletin. 132. Madison (US): Department of natural resources. 22 p.

Hudson N, Baker A, Reynolds D. 2007. Fluorescence analysis of dissolved organic matter in natural, waste and polluted waters: a review. River Ressearch Applications. 23: 631-649. https:// doi.org/10.1002/rra.1005

Kalyoncu H, Zeybek M. 2011. An application of different biotic and diversity indices for assessing water quality: A case study in Rivers Çukurca and Isparta (Turkey). African Journal of Agricultural Research. 6(1): 19-27

Khairuddin, Yamin M, Syukur Abdul. 2016. Analisis kualitas air Kali Ancar dengan menggunakan bioindikator makroinvertebrata. Jurnal Biologi Tropis. 16(2): 10-22. https://doi.org/10. 29303/jbt.v16i2.220

Krebs CJ. 1989. Ecological methodology. New York (US): Harper Collins Publishers, Inc. 654 p

Krisanti M, Effendi H, Wardiatno $\mathrm{Y}$, Hariyadi S, Pratiwi NTM, Mursalin, Andriana W. 2010. Struktur komunitas makroavertebrata sebagai indikator keberadaan bahan organik di perairan hulu Sungai Cisadane Bogor, Jawa Barat. In: Prosiding Seminar Nasional Tahunan VI Penelitian Masalah Lingkungan di Indonesia. Ikatan Ahli Teknik Penyehatan dan Lingkungan Indonesia, Denpasar, Bali. 29 Juli 2010. Bali (ID).

Krisanti M, Wardiatno Y, Anzani YM. 2017. Assessin the ecological status of the Cisadane River's headwaters using benthic macroinvertebates. IOP Conf. Series: Earth and Environmental Science. 54: 1-7. $\quad$ https://doi.org/10.1088/1755-1315/54/ $1 / 012023$

Li L, Zheng B, Liu L. 2010. Biomonitoring and bioindicators used for river ecosystems: Definitions, approaches and trends. Procedia Environmental Sciences. 2: 1510-1524. https://doi.org/10.1016/ j.proenv.2010.10.164

Li J, Luo G, He Ld, Xu J, Lyu J. 2018 Analitycal approaches for determining chemical oxygen demand in water bodies: a review. Critical Reviews in Analytical Chemistry. 48(1): 47-65. https:// doi.org/10.1080/10408347.2017.1370670

Mason CF. 1991. Biology of freshwater pollution. Ed ke-2. New York (US): Longman, Inc. $351 \mathrm{p}$

McCafferty WP. 1983. Aquatic entomology: The fishermen's and ecologist's illustrated guide to insects and their relatives. London (GB): Jones and Bartlett Publishers 480p.

Moran J. 2016. Application of family biotic index in assessment of two rivers affected oil pollution in Assam, India. International Research Journal Environment Science. 5(11): 35-40.

Nakin MDV, Bovungana AQ, Majiza VN. 2017. Spatial and temporal variations in the distribution of benthic macroinvertebrates along the Vuvu River, South Africa. In: Brebbia CA, Boukalova Z. WIT Transactions on Ecology and The Environment; 2017; Boston, United State. Boston (US): WIT Press. $\quad 47-56 \quad$ p. https://doi.org/10.2495/ WRM170051

Odum EP. 1993. Dasar-dasar ekologi. Ed ke-3. Samingan T, penerjemah. Yogyakarta (ID): Gadjah Mada University Press. 697hlm.

Oruta NJ, Oindo BO, Bosire EK. 2017. Relationship between riparian vegetation cover and macroinvertebrate assemblages in Kuywa River, 
Kenya. Researchjournali's Journal of Ecology. 4(1): $1-21$.

Patang F, Soegianto A, Hariyanto S. 2018. Benthic macroinvertebrates diversity as bioindicator of water quality of some rivers in East Kalimantan, Indonesia. International Journal of Ecology. 2018: 1-11. https://doi.org/10.1155/2018/5129421

Pennak RW. 1978. Fresh-water invertebrates of the United States. Second Edition. New York (US): Jhon Wiley \& Sons

Uherek CB, Gouveia FBP. 2014. Biological monitoring using macroinvertebrates as bioindicators of water quality of Maroaga Stream in the Maroaga Cave System, Presidente Figueiredo, Amazon, Brazil. International Journal of Ecology. 2014: 1-7. https://doi.org/10.1155/2014/308149

Ward JV. 1992. Aquatic insect ecology: Biology and habitat. New York (US): John Wiley \& Sons, Inc. 438 $\mathrm{p}$

Warman I. 2015. Uji kualitas air muara Sungai Lais untuk perikanan di Bengkulu Utara. Jurnal Agroqua. 13(2): 24-33
[WAV] Water Action Volunteers. 2003. Citizen monitoring biotic index. [Internet]. [diunduh 2019 Apri 06] Tersedia pada http://www.waterresearch.net/Waterlibrary/Lake/Bugs.pdf

Wildan, DM. 2017. Pemanfaatan Perairan Karst sebagai Media Pemeliharaan Udang Vaname (Litopenaeus vannameI). [Tesis]. Bogor (ID): Institut Pertanian Bogor.

Wimbaningrum $\mathrm{R}$, Indriyani $\mathrm{S}$, Retnaningdyah $\mathrm{C}$, Arisoesilaningsih E. 2016. Monitoring water quality using biotic indices of benthic macroinvertebrates along surface water ecosystems in some tourism areas in East Java, Indonesia. Journal of Indonesian Tourism and Development Studies. 4 (2): $\quad$ 81-90. https://doi.org/10.21776/ ub.jitode.2016.004.02.06

Yunitawati, Sunarto, Hasan Z. 2012. Hubungan antara karakteristik substrat dengan struktur komunitas makrozoobenthos di Sungai Cantigi, Kabupaten Indramayu. Jurnal Perikanan dan Kelautan. 3(3): 221-227. 